\title{
Characteristics of functional subsystems of modular didactic production system for gear trains
}

Piotr JASKÓLSKI, Krzysztof NADOLNY

DOI: 10.30464/jmee.2019.3.4.301

Cite this article as:

Jaskólski P., Nadolny K. Characteristics of functional subsystems of modular didactic production system for gear trains. Journal of Mechanical and Energy Engineering, Vol. 3(43), No. 4, 2019, pp. 301-308.

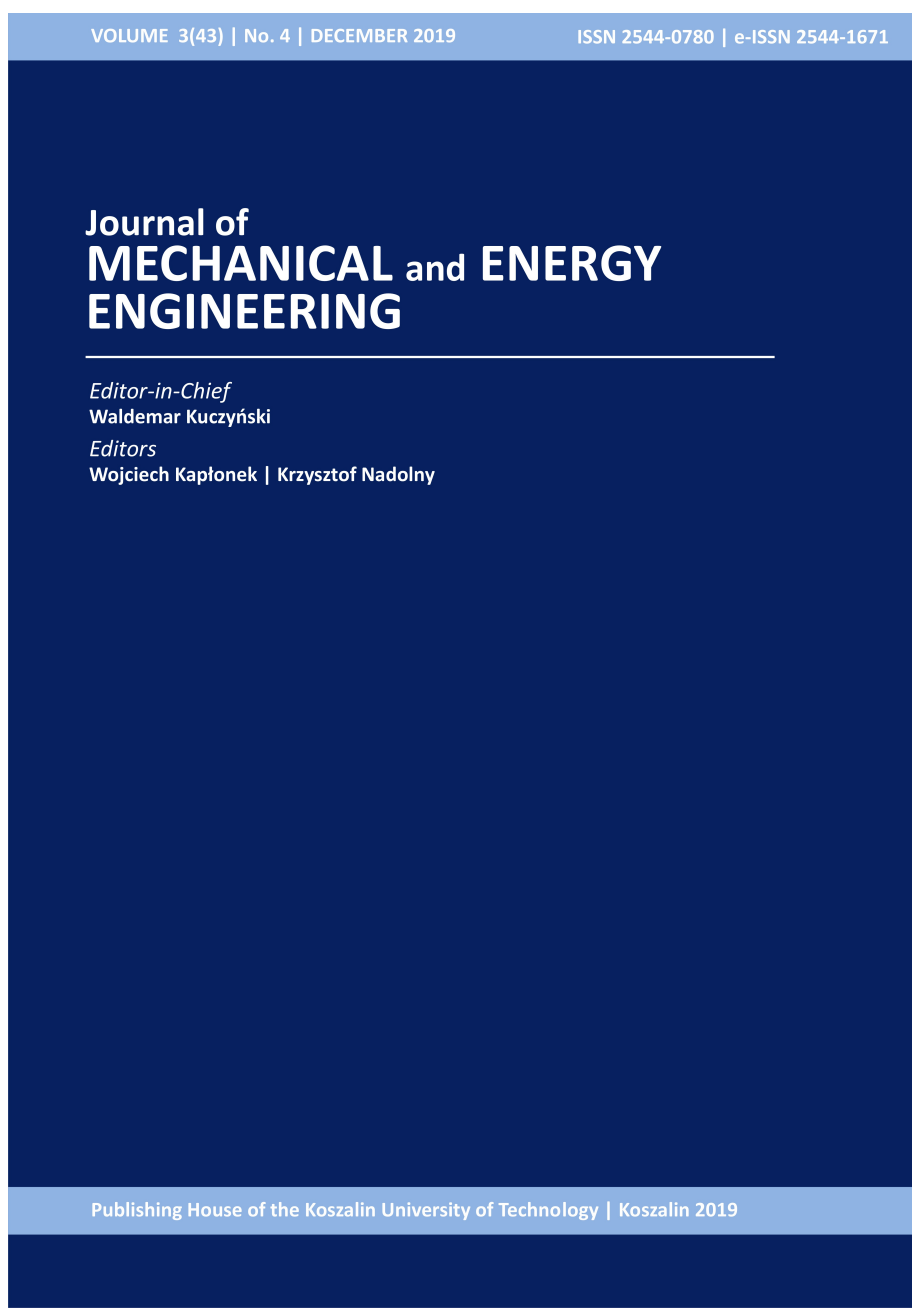

Journal of Mechanical and Energy Engineering

Website: jmee.tu.koszalin.pl

ISSN (Print): 2544-0780

ISSN (Online): 2544-1671

Volume: 3(43)

Number: 4

Year: 2019

Pages: $301-308$

Article Info:

Received 15 January 2020

Accepted 31 January 2020

\section{Open Access}

This article is distributed under the terms of the Creative Commons Attribution 4.0 (CC BY 4.0) International License (http://creativecommons.org/licenses/by/4.0/), which permits unrestricted use, distribution, and reproduction in any medium, provided you give appropriate credit to the original author(s) and the source, provide a link to the Creative Commons license, and indicate if changes were made. 


\title{
CHARACTERISTICS OF FUNCTIONAL SUBSYSTEMS OF MODULAR DIDACTIC PRODUCTION SYSTEM FOR GEAR TRAINS
}

\author{
Piotr JASKÓLSKI ${ }^{1 *}$, Krzysztof NADOLNY ${ }^{2}$ \\ ${ }^{1 *}$ Faculty of Mechanical Engineering, Department of Production Engineering, Koszalin University \\ of Technology, Raclawicka 15-17, 75-620 Koszalin, Poland, e-mail: piotr.jaskolski@tu.koszalin.pl \\ ${ }^{2}$ Faculty of Mechanical Engineering, Department of Production Engineering, Koszalin University \\ of Technology, Poland, e-mail: krzysztof.nadolny@tu.koszalin.pl
}

(Received 15 January 2020, Accepted 31 January 2020)

\begin{abstract}
This paper presents the characteristics of the subsystems of the modular, didactic production system of single-stage gearboxes. The presented system is equipped with miniatures of devices commonly used in industry. The modular construction of the stand gives the possibility of free modelling of production processes and creates great opportunities for future activities of system development and its use. The paper presents the characteristics of the manufacturing, storage, transport and assembly subsystem and quality control. In the characteristics, the market recognition was presented and selected solutions and devices were described.
\end{abstract}

Keywords: modular production system, didactic production system, production system

\section{INTRODUCTION}

Modular didactic production system (MDSP) is a production line whose aim is to physically simulate the production process of gears. The components of the system are a miniaturized form of equipment commonly used in industry. The applied systems, despite the reduced scale, fully reflect the real systems [5].

All activities that were carried out in the production process had to be closely coordinated with the capabilities of the equipment operating in the nest zone. The idea was to write a program for the robot, which would take the components for assembly from strictly defined coordinates, assemble them on the designed assembly station, and do it with great precision, so that the finished product would be properly assembled. When working on the precision, the right speed had to be chosen. The robots were to perform the activities as fast as possible, as far as full repeatability and no loss of positioning accuracy at the coordinates were possible [10].

The MDSP system consists of the following modules, which are numbered as shown in Figures 1 and 2 [6].
1. Component manufacturing station using the additive method for rapid prototyping of FDM.

2. The R1 robot arm is designed for the transport of components.

3. A rail for the R1 robot arm to extend its working range [5].

4. Quality control station for components and finished products.

5. Intermediate Product Warehouse.

6. S1 belt conveyor transporting elements from $\mathrm{S} 1 \mathrm{a}$ to $\mathrm{S} 1 \mathrm{~b}$ [5].

7. R2 robot arm for transport and assembly.

8. Aassembly station.

9. S2 belt conveyor transporting elements from $\mathrm{S} 2 \mathrm{a}$ to $S 2 b$ [5].

10. Pallet depot.

11. Warehouse for finished goods with a landfill site. The following sub-systems can be distinguished for the described gear production system [5]:

- the manufacturing subsystem;

- the storage subsystem;

- transport and assembly subsystem;

- the quality control subsystem.

The aforementioned subsystems are further described in this article. 


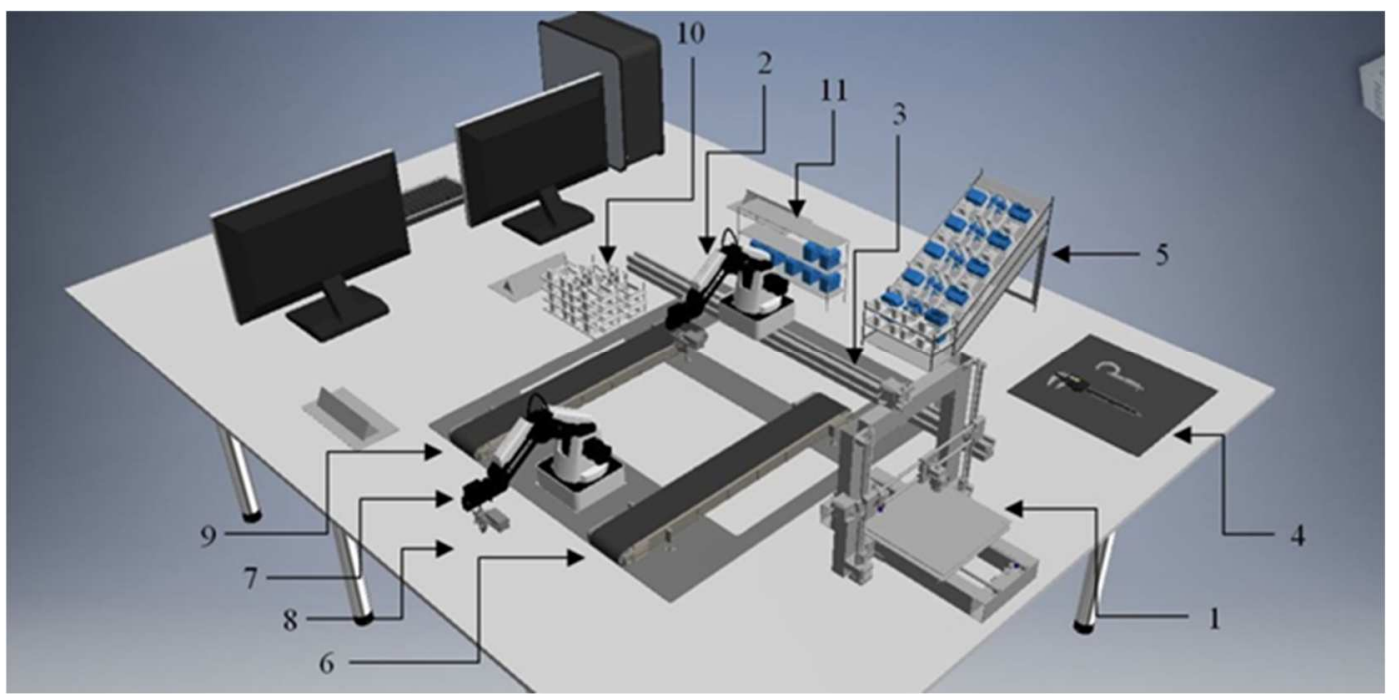

Fig. 1. Didactic, modular production system MDSP [5]

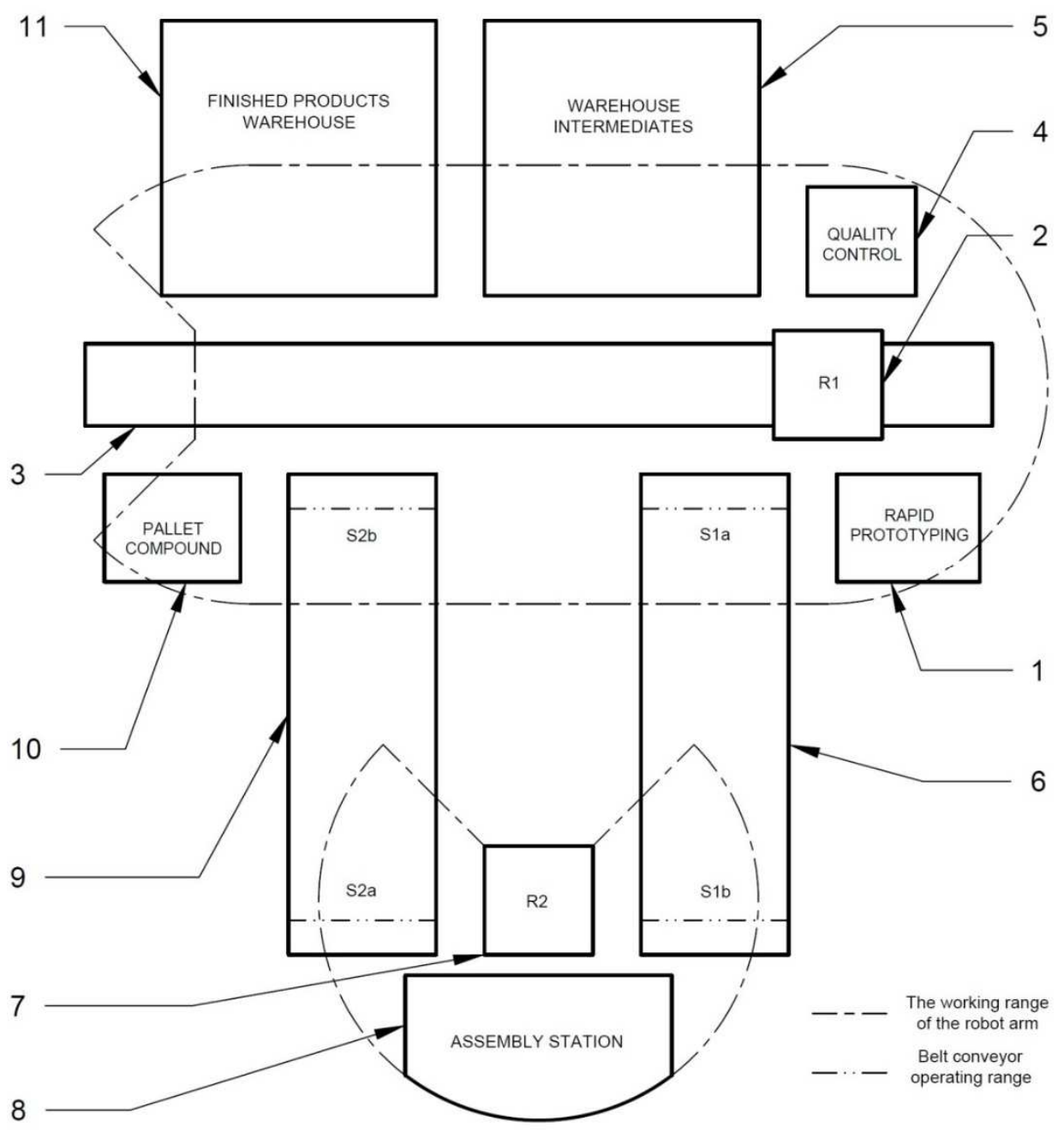

Fig. 2. Diagram of the MDSP single-stage gearing concept [5] 


\section{MANUFACTURING SUBSYSTEM}

For the MDSP manufacturing subsystem, a solution has been adopted, in which gear components will be manufactured using an additive method of fast FDM prototyping. Having recognized the market in the field of devices for incremental FDM manufacturing of components, it was decided to use the Solveere UP Plus 2 device (presented in Figure 3). It is distinguished from the competition by its open casing, stable frame construction and high resistance to damage [5].

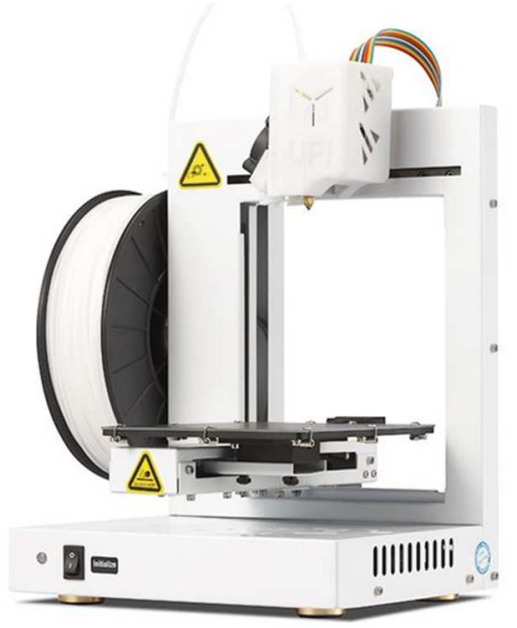

Fig. 3. Solveere FDM UP Plus 2 incremental model making device [1]

UP Plus 2 is a device with a working area of $14 \times 14 \times 13.5 \mathrm{~cm}$. It is possible to produce elements from ABS (Acrylonitrile Butadiene Styrene) and PLA (PolilacticAcid) materials. The device is equipped with a heated table which heats up to $100^{\circ} \mathrm{C}$. Thanks to this, the manufactured elements stick to it better and are not deformed by uneven cooling of subsequent layers. The thickness of the manufactured layers, depending on the set parameters, ranges from $0.15-0.4 \mathrm{~mm}$. Detailed technical specification of the device is presented in Table 1 [1].

The device for incremental component manufacturing using the FDM UP Plus 2 method is controlled by a computer with installed dedicated UP! version 2.0. Programming begins with placing and positioning the model in the $\mathrm{X}, \mathrm{Y}$ and $\mathrm{Z}$ axes in the virtual manufacturing area. For proper positioning, the program has functions such as shift, rotation and scaling. Then the extrusion parameters such as layer thickness, model filling level, support setting, work table temperature etc. are set [7]. Programming of the FDM device is presented in Figure 4.

Tab. 1. Technical specifications of the Solveere UP Plus 2 device [1]

\begin{tabular}{ll}
\hline $\begin{array}{l}\text { Manufacturing } \\
\text { technology }\end{array}$ & $\begin{array}{l}\text { Melted and Extruded } \\
\text { Manufacturing }\end{array}$ \\
\hline Workspace size & $140 \times 140 \times 135 \mathrm{~mm}$ \\
\hline Thickness & $0.15 / 0.20 / 0.25 / 0.30 / 0.35 / 0.40 \mathrm{~mm}$ \\
\hline Material & ABS, PLA \\
\hline Connectivity & USB \\
\hline Operating system & Win XP/Vista/7/8, Mac OS \\
\hline Power & $110-240 \mathrm{~V} \mathrm{AC}, 50-60 \mathrm{~Hz}, 220 \mathrm{~W}$ \\
\hline Future & $5 \mathrm{~kg}$ \\
\hline
\end{tabular}

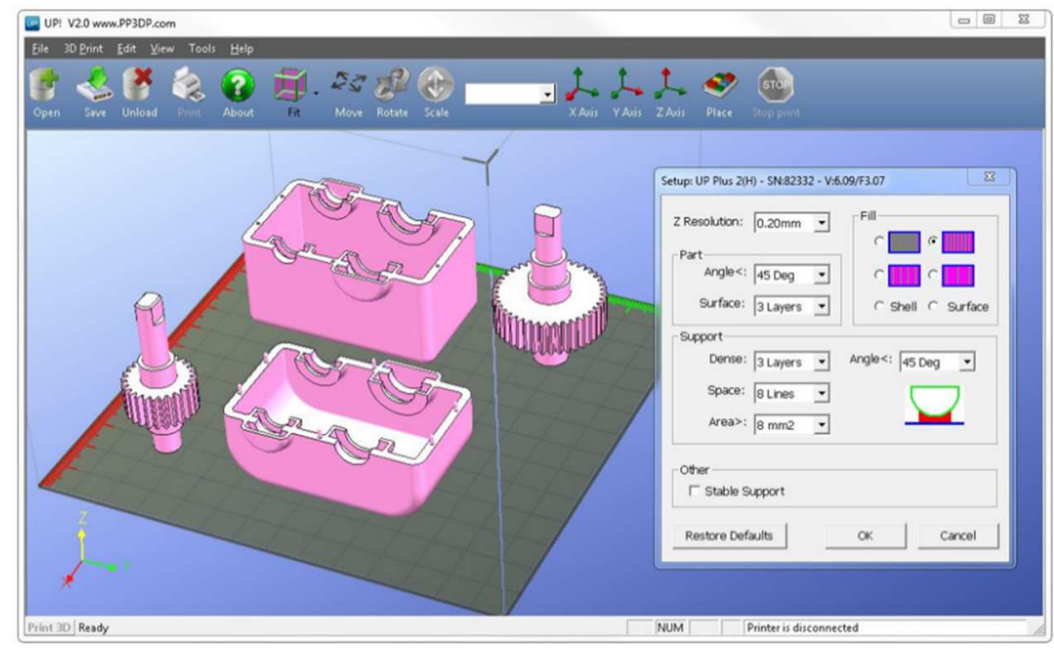

Fig. 4. Preparation of components for FDM manufacturing in UP! ver. 2.0 [5] 
The process of manufacturing single-stage transmission components in the constructed MDSP system is presented in Figure 5 [5].

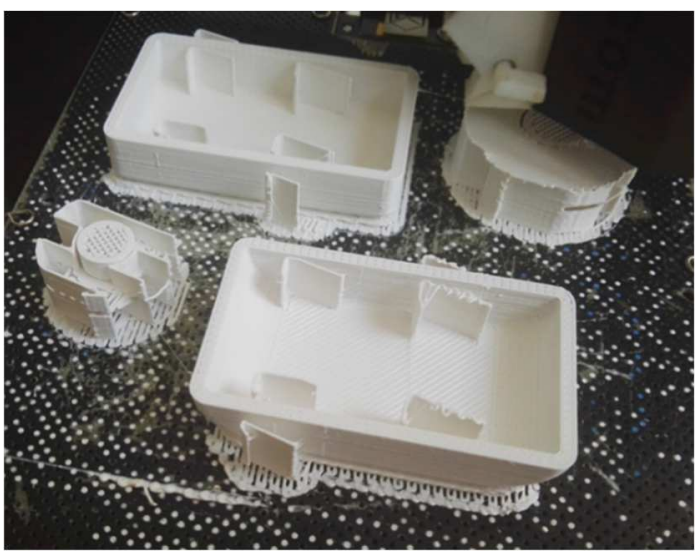

Fig. 5. Process of manufacturing single-stage gearbox components using the FDM method [5]

\section{THE STORAGE SUBSYSTEM}

The following subsections present a solution in which warehouses will be divided into two subsystems: a warehouse for semi-finished products and a warehouse for finished products with a production waste dump.

\subsection{Warehouse for semi-finished products}

For the semi-finished product warehouse, a solution has been adopted in which pallets with single-stage gear components will be stored on flow racks. An example of a flow rack is shown in Figure 6. However, the design of the rack shown in this drawing would have to be modified to be used in the MDSP system. Firstly, the rack would have to be miniaturised. Secondly, due to the positioning of the robot arm jaws, the pallets leaving the flow storage would have to be fed in a horizontal position and not in an oblique position, as is the case with a typical solution [5].

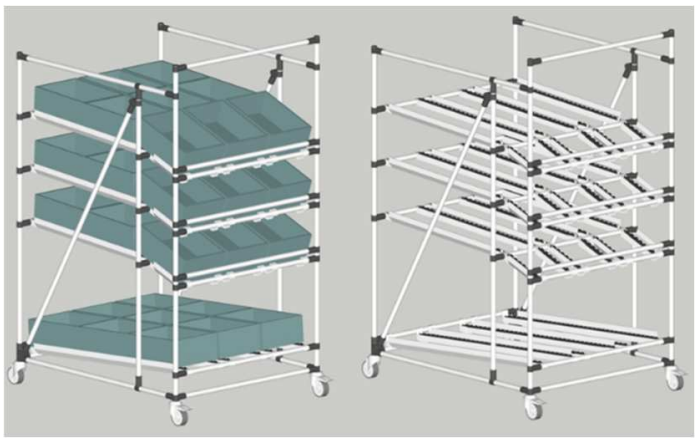

Fig. 6. Digital 3D model storage rack, flow rack [8]

\subsection{Finished product storage}

After a market analysis and a review of the various companies' offers, a solution was chosen that uses the finished goods warehouse module from the didactic mechatronic modular system from Bosch Rexroth (Figure 5). This warehouse was selected mainly because it was designed and adapted to store elements resembling housings of single-stage gearboxes produced in the MDSP system [2].

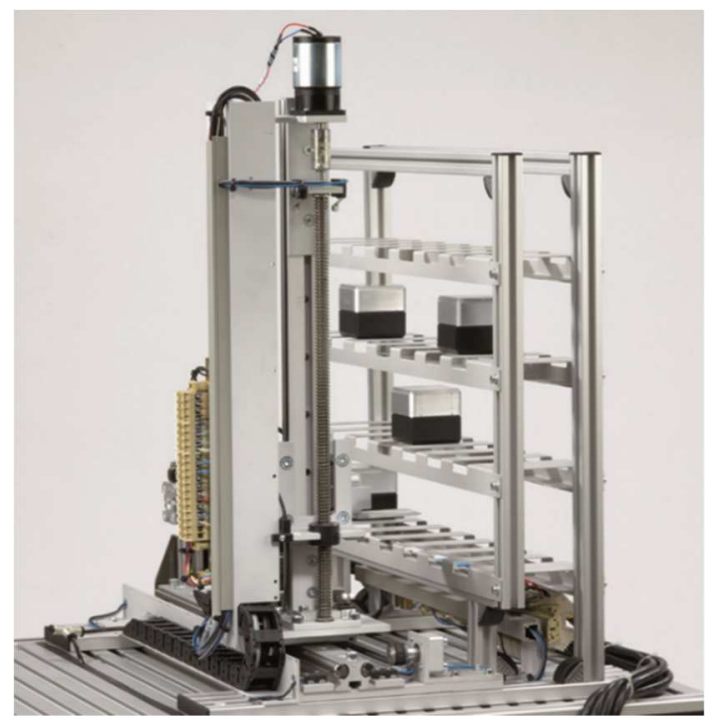

Fig. 7. Warehouse of finished products modular Mechatronic Modular System MMS from Bosch Rexroth [2]

\section{TRANSPORT AND ASSEMBLY SUBSYSTEM}

After market analysis in the field of robot arm thumbnails and belt feeders, it was decided to use Dobot machines from China. The greatest advantage of these machines is that they were designed for teaching purposes, so that components can be combined in different configurations. Moreover, the devices of this company are characterized by high positioning accuracy, high quality of manufacture and reasonable price. In the adopted solution, the transport and assembly subsystem in the MDSP system was configured from five Dobot devices. These are two robot arms, one rail for the robot arm and two belt conveyors [11].

\subsection{Robot arm}

The Dobot Magician robot arm is a didactic miniature of industrial manipulators used in car factories, automated production lines, and factories where there is a risk to human health. By using various interchangeable end tools, the Dobot Magician is able to draw, engrave, produce FDM parts and move objects. The Dobot Magician's arm with the final tool for moving parts is shown in Figure 6 [3]. 


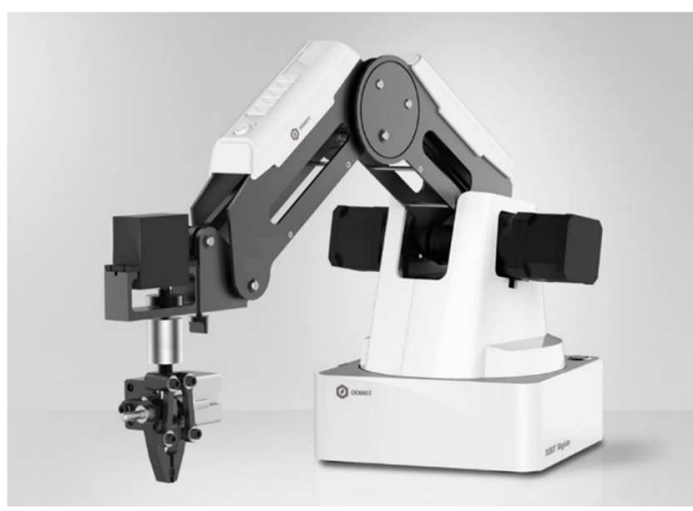

Fig. 8. Robot arm Dobot Magician [3]

The dimensions of the device base are $158 \times 158$ $\mathrm{mm}$. It moves in four axes, can lift workpieces weighing up to 500 grams and has a positioning accuracy of $\pm 0.2 \mathrm{~mm}$. As a final tool in the configuration for the MDSP system, a pneumatic gripper will be used to move the elements. The operating range of the gripper is $27.5 \mathrm{~mm}$ and its clamping force is $8 \mathrm{~N}$. Table 2 shows detailed technical specifications of the device [3].

In the adopted solution, the two Dobot Magician arms are the control units of the MDSP. Each arm is equipped with 13 additional ports for connecting other modules. The MDSP system will connect three distance sensors, a suction pump, a rail for the robot arm and two belt conveyors. A description of the individual ports of the device is shown in Figure 9.

The Dobot Magician robot arms are controlled by a computer with dedicated DobotStudio software installed. This program has a Blockly module, thanks to which it is possible to program devices in a graphic way by combining blocks corresponding to particular functions.
The Dobot Magician arm in the constructed MDSP system is presented in Figure 10 [5].

Tab. 2. Technical specifications of the robot arm Dobot Magician [3]

\begin{tabular}{|c|c|}
\hline Base dimensions & $158 \times 158 \mathrm{~mm}$ \\
\hline Device dimensions & $307 \times 224 \times 330 \mathrm{~mm}$ \\
\hline Number of axes & 4 \\
\hline Lifting capacity & $500 \mathrm{~g}$ \\
\hline $\begin{array}{l}\text { Maximum operating } \\
\text { range }\end{array}$ & $320 \mathrm{~mm}$ \\
\hline Positioning accuracy & $\pm 0.2 \mathrm{~mm}$ \\
\hline Connectivity & USB/WiFi/Bluetooch \\
\hline Software & $\begin{array}{l}\text { DobotStudio, Repetier Host, } \\
\text { GrblController3.6, Dobot } \\
\text { Blockly }\end{array}$ \\
\hline $\begin{array}{l}\text { Pneumatic gripper } \\
\text { (range/force) }\end{array}$ & $40 \mathrm{~mm} / 8 \mathrm{~N}$ \\
\hline Power supply & $100-240 \mathrm{~V}, 50 / 60 \mathrm{HZ}$ \\
\hline $\begin{array}{l}\text { Power supply of the } \\
\text { device }\end{array}$ & $12 \mathrm{~V} / 7 \mathrm{~A} \mathrm{DC}$ \\
\hline Power consumption & 60 W Max \\
\hline Operating temperature & $10-60^{\circ} \mathrm{C}$ \\
\hline
\end{tabular}

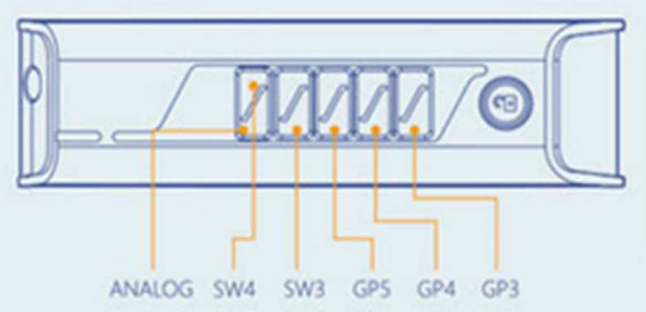

ANALOG SW4 SW3 GPS GP4 GP3

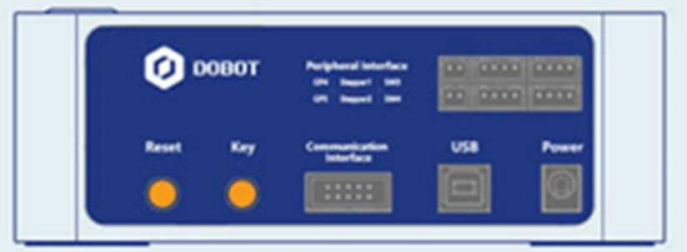

Fig. 9. Description of ports of the Dobot Magician robot arm [4] 


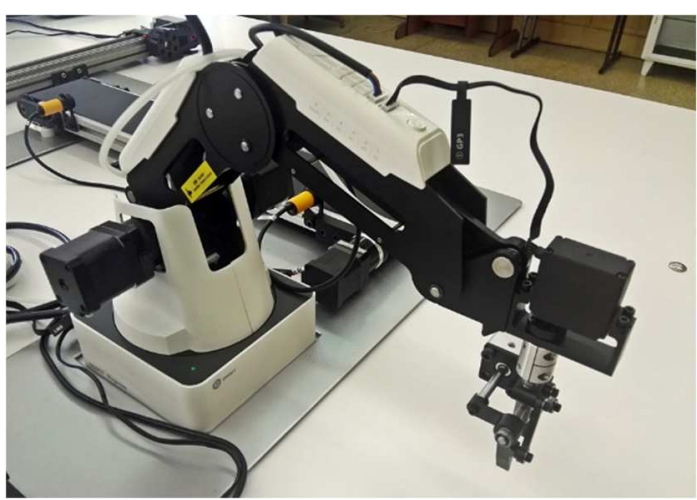

Fig. 10. DOBOT Magician robot arm in the constructed MDSP system [5]

\subsection{Transport rail for the robot arm}

The system will use a Sliding Rail Kit for the Dobot Magician robot arm. It allows to extend the range of the arm in the $\mathrm{X}$ axis by one metre. The MDSP system will be connected to the R1 arm. Thanks to its application, the R1 robot will cover the rapid prototyping station, quality control station, semifinished products warehouse, finished products warehouse, pallet storage and two belt feeder points. This device is presented in Figure 11.

The rail dimensions are $1320 \times 120 \times 55 \mathrm{~mm}$, the maximum travel speed is $150 \mathrm{~mm} / \mathrm{s}$, the maximum acceleration is $150 \mathrm{~mm} / \mathrm{s}^{2}$ and the position repeatability is $0,01 \mathrm{~mm}$. Detailed specifications are shown in Table 3 [3].

Figure 12 shows a Sliding Rail Kit with a Dobot Magician robot arm mounted in a built MDSP system.

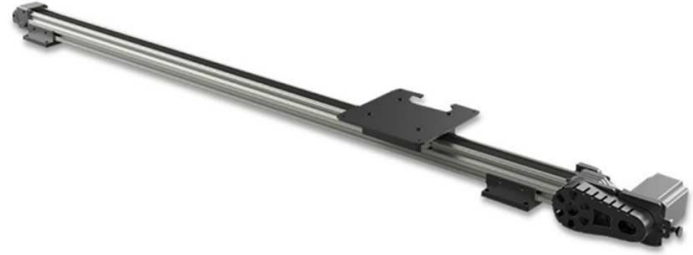

Fig. 11. Sliding Rail Kit for Dobot Magician robot arm [3]

Tab. 3. Technical specifications of Sliding Rail Kit for robot arm Dobot Magician [3]

\begin{tabular}{ll} 
Maximum lifting capacity & $5 \mathrm{~kg}$ \\
\hline Operating range & $1000 \mathrm{~mm}$ \\
\hline Maximum speed & $150 \mathrm{~mm} / \mathrm{s}$ \\
\hline Maximum acceleration & $150 \mathrm{~mm} / \mathrm{s}^{2}$ \\
\hline $\begin{array}{l}\text { Repeatability accuracy of } \\
\text { position }\end{array}$ & $\pm 0.01 \mathrm{~mm}$ \\
\hline Absolute position accuracy & $\pm 0.25 \mathrm{~mm}$ \\
\hline Future & $4.7 \mathrm{~kg}$ \\
\hline Weight with packaging & $7.23 \mathrm{~kg}$ \\
\hline Dimensions & $1320 \times 120 \times 55 \mathrm{~mm}$ \\
\hline
\end{tabular}

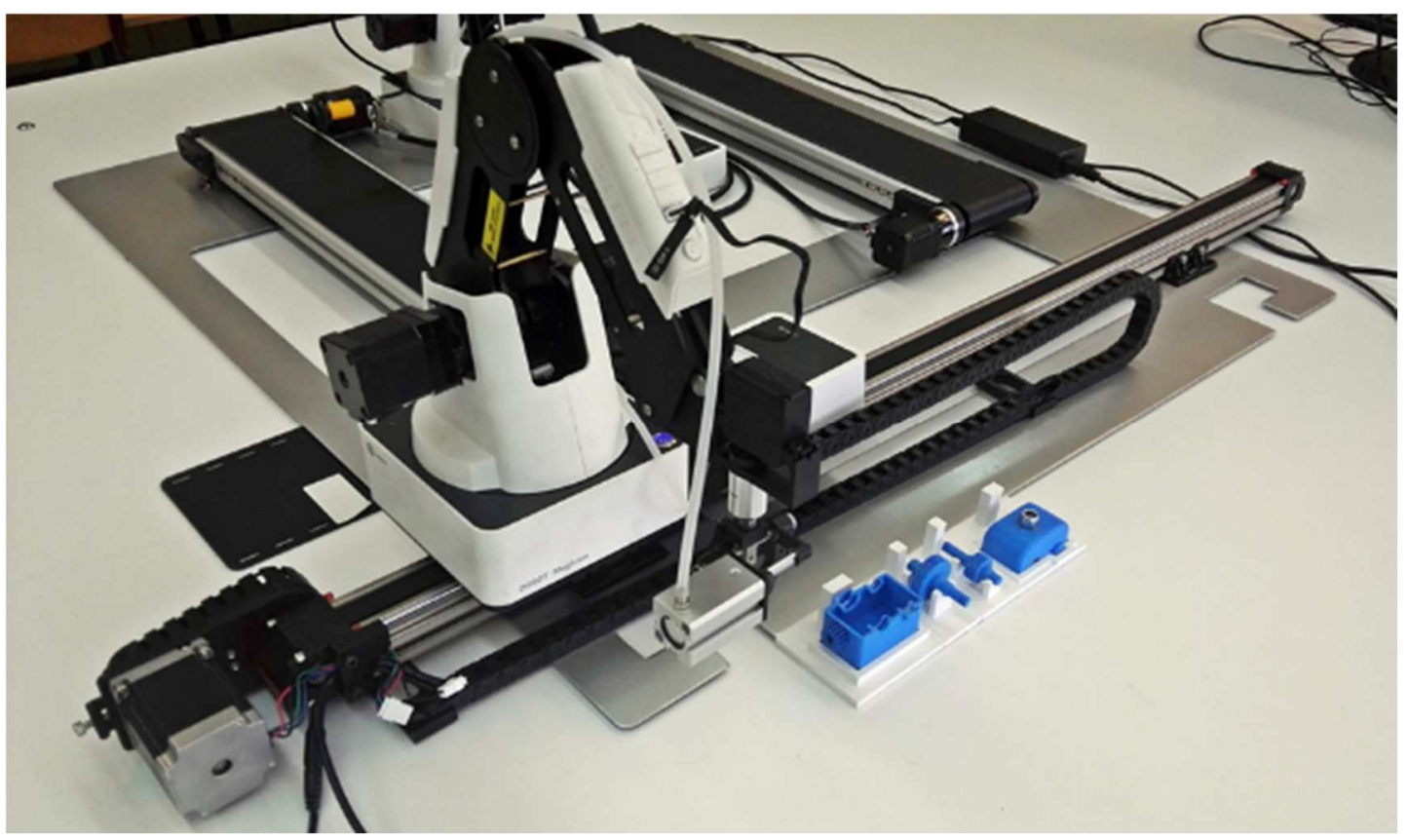

Fig. 12. Sliding Rail Kit with Dobot Magician robot arm mounted in the constructed MDSP system [5] 


\subsection{Belt feeder}

The adopted solution assumes the use of the Conveyor Belt Kit from Dobot, designed for the Dobot Magician robot. The belt conveyor has a speed control and is equipped with a distance sensor, which allows to simulate the production line. This device is shown in Figure 13

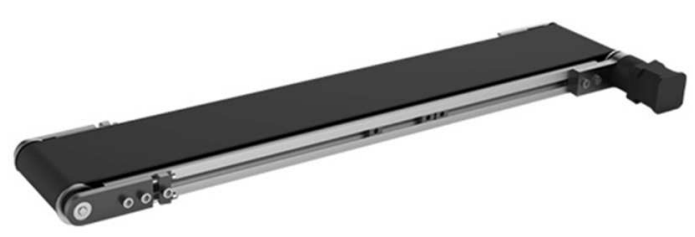

Fig. 13. Conveyor Belt Kit dedicated for Dobot Magician robot arm [3]

The belt conveyor allows for the movement of elements over a distance of $600 \mathrm{~mm}$. Its maximum speed is $120 \mathrm{~mm} / \mathrm{s}$, maximum acceleration is 1100 $\mathrm{mm} / \mathrm{s}^{2}$ and maximum load capacity is 500 grams. Detailed specification of the device is presented in Table 4 [3].

Tab. 4. Technical specifications of the Conveyor Belt Kit by Dobot [3]

\begin{tabular}{ll}
\hline Maximum lifting capacity & $500 \mathrm{~g}$ \\
\hline Operating range & $600 \mathrm{~mm}$ \\
\hline Maximum speed & $120 \mathrm{~mm} / \mathrm{s}$ \\
\hline Maximum acceleration & $150 \mathrm{~mm} / \mathrm{s}^{2}$ \\
\hline Future & $4.2 \mathrm{~kg}$ \\
\hline \begin{tabular}{l} 
Dimensions \\
\hline $\begin{array}{l}\text { Distance sensor measuring } \\
\text { range }\end{array}$
\end{tabular} & $20-150 \times 215 \times 60 \mathrm{~mm}$ \\
\hline
\end{tabular}

Distance sensor supply voltage $4.5-5.5 \mathrm{~V}$

The MDSP system assumes that both belt feeders (S1 and S2 marked in Figure 1 and 2) will be connected and controlled by the R2 robot arm. There will be two distance sensors in the S1 feeder: the first one integrating the work of the two robot arms mounted at point S1a and the second stopping the line mounted at point S1b. The S2 will have only one distance sensor to stop the line at point $\mathrm{S} 2 \mathrm{~b}$. The belt in the constructed MDSP system is shown in Figure 14 [5].

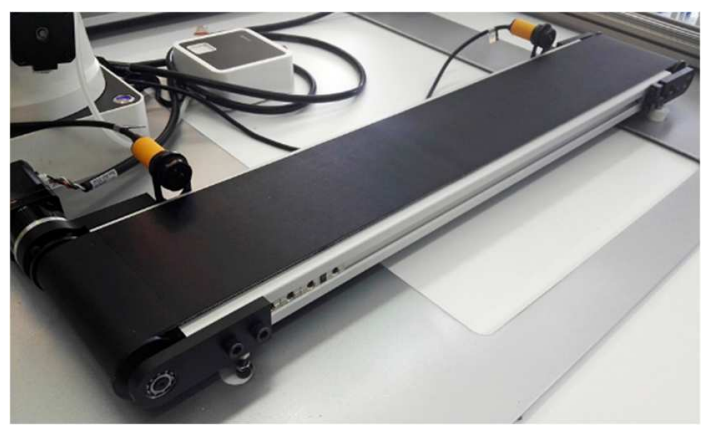

Fig. 14. Belt feeder dedicated to robot arm Dobot Magician in the constructed MDSP system [5]

\section{THE QUALITY CONTROL SUBSYSTEM}

In the following subsections it is proposed to implement a solution in which quality control will be divided into the control of components manufactured using the FDM method and the control of complex single-stage gearboxes [5].

\subsection{Quality control of single-stage gearbox components}

For the quality control of the components, it is assumed that a solution will be applied in which the critical points that come into contact with each other after the components are manufactured and processed. Accuracy at these points is paramount, as deviations could cause the gearbox to be incorrectly assembled on the assembly station. In the proposed solution, the control of the shaft and body sensitivities will be carried out by measuring the contact planes with a caliper and checking that the measurements are within tolerance [9].

The Parkinson method has been selected to measure the accuracy of gear mesh. In this method, one idler shaft is placed on an adjustable saddle with a motor that sets the shaft in motion. The second shaft with the wheel is placed on a moving trolley, which, depending on the accuracy of the gears, can be moved closer or further away from the first shaft with the wheel. During the measurement, the moving trolley adheres to the dial gauge, from which you can read out the gear mesh deviations [5].

\subsection{Quality control of complex single-stage gearboxes}

To control the quality of finished products, a solution was adopted in which a shaft with an active gear is driven in a complex gear. Then, with the use of a tachometer, the speed of the sprocket shaft is checked. The readout from the tachometer will prove the correctness of the folded gear [5]. 


\section{SUMMARY AND CONCLUSIONS}

After becoming familiar with the MDSP subsystems, the following conclusions can be drawn.

1. One of the biggest problems when designing models of production systems in a reduced scale is the limited choice of equipment thumbnails.

2. Having recognized the market in the field of production equipment thumbnails, it was possible to find adequate solutions from Dobot, which allow for automation of transport and assembly processes.

3. There are no ready-made solutions for several of the adopted subsystems on the market, so they had to be designed for the MDSP system.

4. In some subsystems there was a problem with process automation, which made it necessary to introduce manual (manual) processes.

5. Thanks to additional ports in Dobot Magician arm, it is possible to expand the system with, for example, vision systems or Arduino controllers.

\section{Nomenclature}

\section{Acronyms}

DMSP - modular didactic production system

FDM - fused deposition modeling

\section{References}

1. http://www.up3d.pl (accessed: May 2018)

2. https://www.boschrexroth.com (accessed April 2018)

3. https://www.dobot.cc (accessed: May 2018)

4. https://botland.com.pl/ramiona-robotow/7103-ramierobota-dobot-magician-advanced-educational-plan.html (accessed: May 2018)

5. Jaskólski P., 2018, Projekt techniczno-organizacyjny modułowego dydaktycznego systemu produkcji przekładni zębatych, Politechnika Koszalińska

6. Jaskólski P., Nadolny K., 2019 Characteristic of process flow in modular didactic production system for gear trains

7. Chlebus E., 2003 Innowacyjne metody inżynierskie w zintegrowanym rozwoju produktu i procesów wytwarzania, Mechanik, 76, 1, 5-11

8. http://flexlean.pl/regaly-przemyslowe/ (accessed: May 2018)

9. Knop K., 2017, Analiza udziału i znaczenia stosowanych metod kontroli jakości do wykrywania niezgodności profili aluminiowych, Systemy wspomagania w inżynierii produkcjiJakość, Bezpieczeństwo, Środowisko, 6, 7, 129-142

10. Kaczmarek W., Panasiuk J., 2017, Robotyzacja procesów produkcyjnych, Wydawnictwo naukowe PWN SA.

11. Kaczmarek W., 2008, Elementy robotyki przemysłowej, WAT, Warszawa

\section{Biographical notes}

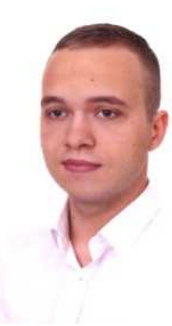

Piotr Jaskólski defended his diploma thesis with honors in 2018 at the Faculty of Mechanical Engineering of the Koszalin University of Technology, majoring in Management and Production Engineering, specializing in Computer Technology in Production Engineering. During his studies and diploma thesis he was the leader of a team of students performing a physical model of a modular didactic production system, leading to its launch and implementation into didactic classes in the field of Management and Production Engineering. Currently he is an employee of the Koszalin University of Technology at the Faculty of Mechanical Engineering. His scientific interests include issues related to automation of manufacturing processes and modern technologies in production engineering.

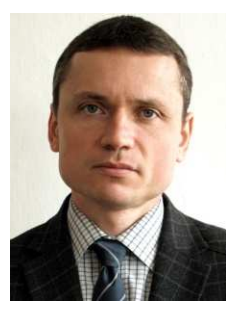

Krzysztof Nadolny received his M.Sc. degree in Mechanics and Machine Design and next the Ph.D (with honors) as well as D.Sc. degree in Machinery Construction and Operation from the Koszalin University of Technology, in 2001, 2006 and 2013, respectively. Since 2006, he has been a researcher in the Department of Production Engineering at the Koszalin University of Technology, where currently he works as an associated professor and the head of the research-didactic team for production planning and control. His scientific interests focus on problems concerning machining processes and tools, efficiency, monitoring and diagnostics of machining processes as well as tribology. He has participated in 2 international and 3 national research projects, presenting results of his work at 10 international and 21 national conferences, published more than 230 scientific papers in international and national journals, book chapters, as well as conference proceedings. He is also the author of 6 monographs and 13 national patents. 